\title{
Sadakat Programına Yönelik Tutum, Mağaza Memnuniyeti, Mağaza Sadakati ve Satın Alma Niyeti Arasındaki Etkileşim: Kozmetik Perakendeciliği Örneği ${ }^{1}$
}

The Interaction Between Attitude Towards Loyalty Programs on Store Satisfaction, Store Loyalty and Purchase Intention: The Case of Cosmetics Retailers

\section{Merve Türk² - Dr. Öğr. Üyesi Tutku Eker İscioğlu}

Başvuru Tarihi: 18.11.2019

Kabul Tarihi: 01.06.2020

Makale Türü: Araştırma Makalesi

Öz

Günümüzde hızla artan rekabet, kozmetik perakendeciliği sektöründe de etkisini göstermiş ve perakendecileri tüketici bağlılı̆̆ın ve satışları arttırmayı hedefleyen sadakat programları geliştirmeye yöneltmiştir. Sadakat programlarının bir çeşidi olan sadakat kartları ile tüketicilere sunulan faydalar, maddi/sert ve maddi olmayan/yumuşak faydalar olarak ikiye ayrlabilir. Bu araştırmanın amacı, farklı faydalar sunan kozmetik perakendecilerinin, sadakat kartlarını kullanan tüketicilerin sadakat programlarna yönelik tutumu, mağaza memnuniyeti, mağaza sadakati ve 103atin alma niyeti arasındaki etkileşimi incelemektir. Araştırmada, sert ve yumuşak faydaları tüketicilerine sunan Sephora mağazası ile sadece sert faydalar sunan Gratis mă̆azasını tercih eden 200 katılımcıdan çevrimiçi anket formu ile veriler toplanmıştır. Araştırma amacına uygun olarak geliştirilen araştırma modeli, "Kısmi En Küçük Kareler Yöntemine Dayalı Yapısal Eşitlik Modellemesi” ve "Çoklu Grup Analizi” ile test edilmiştir. Bulgulara göre, sadakat programına yönelik tutum, hem Gratis hem de Sephora için mağaza memnuniyeti ve mă̆aza sadakati ile sonuçlanırken, sadece Gratis için 103atin alma niyeti yaratmıştır. Öte yandan, mağaza memnuniyeti sadece Gratis için mağaza sadakati üzerinde olumlu etki oluşturmuş, ancak her ikisi için de 103atin alma niyeti ile sonuçlanmamıştır. Mağaza sadakati ise, Gratis'e yönelik 103atin alma niyeti üzerinde olumlu etki yaratırken, Sephora için bu etki gerçekleşmemiştir.

Anahtar Kelimeler: Sadakat Programına Yönelik Tutum, Mağaza Memnuniyeti, Mağaza Sadakati, Satın Alma Niyeti, Kozmetik Perakendeciliği

\footnotetext{
${ }^{1}$ Bu çalışma 2019 yllında gerçekleştirilen “Global Business Research Kongresi”nde özet sunulan bildirinin genişletilmiş halidir.

${ }^{2}$ University of Greenwich Business Faculty, Old Royal Naval College, Park Row, London, UK, mt6985y@greenwich.ac.uk, ORCID: 00000002-7409-6637

${ }^{3}$ Piri Reis Üniversitesi, İİB, İșletme Bölümü, teiscioglu@pirireis.edu.tr, ORCID: 0000-0002-4794-6368
} 


\section{Abstract}

Today, increasing competition has been influential in cosmetics retailing as well and has led retailers to implement loyalty programs aiming to increase consumer loyalty and sales. With loyalty cards, one form of loyalty programs, consumers are offered two benefits, which can be divided as monetary/hard and non-monetary/soft benefits. The aim of this study is to examine the relationship between consumers' attitude towards loyalty programs, store satisfaction, store loyalty and purchase intention towards cosmetics retailers offering different benefits. Data was collected with an online questionnaire from 200 participants who preferred either Gratis, which offers hard and soft benefits, or Sephora, which offers only hard benefits. The research model, developed with respect to the aim of research, was tested with "Partial Least Squares Structural Equation Modeling" and "Multi Group Analysis". According to the findings, attitude towards loyalty program has resulted in store satisfaction and store loyalty for both Gratis and Sephora, while creating purchase intention only for Gratis. On the other hand, store satisfaction had a positive effect on store loyalty only for Gratis, but has not resulted in purchase intention for both. While store loyalty has created a positive effect on purchase intention for Gratis, this effect has not been realized for Sephora.

Keywords: Attitude Towards Loyalty Program, Store Satisfaction, Store Loyalty, Purchase Intention, Cosmetics Retailers

\section{Giriş}

Özellikle 1980'lerden bu yana işletmeler, tüketici sadakati oluşturmak ve bu sayede satın alma niyetini artırmak için ilişkisel pazarlama yöntemlerine başvurmaktadır. Bu yöntemlerden biri olan sadakat programları, yeni tüketici kazanımını hedefleyen stratejilere nazaran, işletmelerin mevcut tüketicilere odaklanmalarını amaçlar. Diğer pazarlama stratejilerinin aksine sadakat programları, satın alma miktarını ve sıklığını artırmaya yoğunlaşmaktadır. Sadakat programları işletmelerin tüketicileri hakkında bilgi toplamak, onları elde tutmak, müşteri ilişkilerini ve sadakatini arttırmak için kullandıkları en yaygın pazarlama araçları arasındadır (Kang, Alejandro ve Groza, 2015).

Türkiye'de bankacılık, ulaşım, tekstil, otomotiv ve perakendicilik sektörlerinde yaygın kullanımı bulunan sadakat programlarını, diğer pazarlama kararlarıyla bütünleştiren işletme sayısında artış olduğu görülmektedir. Tüketici sadakati ajansı Ketchup Loyalty Marketing'in, 2017 ve 2018 yıllarını kapsayan tüketici sadakat programları araştırmasına göre, tüketicilerin en az bir kez sadakat programını kullanma oranında bankacılık sektörü \%74'le ilk sırada, otomotiv sektörü \%38’le son sırada yer almaktadır. Perakende sektöründe ise bu oranın \%55 olarak gerçekleştiği görülmüştür (“Ketchup Loyalty Marketing”, t.y.).

Kozmetik sektörü, ülkemizde genç nüfusun fazlalığı, kadınların genç ve güzel görünme tutkusu, erkeklerin kişisel bakımına daha fazla önem vermesi, e-ticaretin gelişmesi ve doğrudan satışın 
artmasıyla hızla büyüyen sektörler arasında yer almaktadır (Bozkuş ve Yılmaz, 2018). 2017 yılında sadece yurtiçinde \%14 büyüyerek 11 milyar TL’ye ulaştı̆̆ tahmin edilen kozmetik pazarında bugün 30 'un üzerinde kozmetik perakendecisi iki binin üzerinde mağazasıyla hizmet vermektedir (Bozkuş ve Yılmaz, 2018). Kozmetik perakendecilerinin sadakat programlarına yönelik istatistiksel bilgiye rastlanmasa da, Ketchup Loyalty Marketing araştırmasında iki kozmetik perakendecisi olan Gratis ve Watsons kartlarının en fazla kullanılan 10 sadakat programı arasında yer aldığı bulgulanmıştır ("Ketchup Loyalty Marketing", t.y.). Buna ek olarak, Gratis'in sadakat programını kullanan tüketicilerin \%57'sinin programa aşı olduğu tespit edilmiştir (“Ketchup Loyalty Marketing”, t.y.).

Rekabetin yoğun yaşandığı sektörlerden biri olan kozmetik perakendeciliğinde, markalar farklı özelliklerde sadakat programları uygulamaktadır ve bunun neticesinde farklı faydalar elde ettikleri düşünülmektedir. Sadakat programları üzerine şu ana kadar gerçekleştirilen araştırmalar, müşterilerin sadakat programlarının faydalarını nasıl algıladıkları (Bose ve Rao, 2011; Radder, Eyk ve Swiegelarr, 2015), algılanan faydaların sadakat programı memnuniyeti üzerindeki etkisi (Mimouni-Chaabane ve Volle, 2010; Hanzaee ve Rezaeyeh, 2013; Omar, Ramly, Alam ve Nazri, 2015), müşteri sadakati (Kim, Lee, Choi, Wu ve Johnson, 2013) ve mağaza sadakati (Omar vd., 2015) gibi konulara yoğunlaşmıştır (aktaran, Kyguoliene, Zikiene ve Grigaliunaite, 2017). Ancak, kozmetik perakendeciliğinde sadakat programına yönelik tutum, memnuniyet, sadakat ve satın alma niyeti arasındaki etkileşimi araştıran ulusal ve uluslararası düzeyde bir araştırmaya ne yazık ki rastlanmamıştır. Bu çalı̧̧a, akademik yazındaki boşluğu doldurma çabası dâhilinde gerçekleştirilmiştir. Dolayısıyla, farklı faydalar sunan kozmetik perakendecilerinin sadakat kartlarını kullanan tüketicilerin sadakat programına yönelik tutumu, mağaza memnuniyeti, mağaza sadakati ve satın alma niyeti arasındaki etkileşimin bu araştırma ile incelenmesi amaçlanmaktadır. Bu doğrultuda, hem sert hem de yumuşak faydaları tüketicilerine sunan Sephora mağazası ile sadece sert faydalar sunan Gratis mağazasının tüketicileri üzerinde araştırma gerçekleştirilmiştir. Önerilen hipotezler ve araştırma modeli, bu iki programdan birini kullanan 200 katılımcıdan toplanan verilerle, "Kısmi En Küçük Kareler Yöntemine Dayalı Yapısal Eşitlik Modellemesi" ve "Çoklu Grup Analizi" ile test edilmiştir. Bulgular dikkate alınarak teorik ve yönetimsel çıkarımlar öne sürülmüştür.

\section{Literatür Taraması ve Hipotezler}

\section{Ilişkisel Pazarlama ve Müşteri Sadakati}

Günümüzde pazarlama teorisi ve pratiği müşteri odaklı yaklaşıma daha fazla önem verir hale gelmiş, yöneticiler uzun vadeli müşteri ilişkileri yaratmaya yönelik hedeflerini daha da artıırmış, zira bunun işletmenin gelir ve karlılığını etkilediği görüşü daha da kesinlik kazanmıştır (Bolton, Lemon ve Verhoef 2002; Gupta, Lehmann ve Stuart, 2004). İlişkisel pazarlama, müşteri elde etme ya da anlık satışları artırma gibi kısa vadeli hedeflerden ziyade, müşteri sadakati ve uzun vadeli müşteri taahhüdü üzerine odaklanan bir müşteri ilişkileri yönetimidir. Öztürk'ün (2003) de ifade ettiği üzere ilişkisel pazarlama, yeni müşteriler edinmeye, var olan müşterileri korumaya ve onlarla ilişkileri geliştirmeye odaklanan bir pazarlama kavramıdır. Bu yaklaşım 
ile, mevcut müşterileri koruma ve elde tutma maliyetinin, yeni müşteriler bulma ve onları karlı müşterilere dönüştürme maaliyetinden çok daha az olduğu düşünülmektedir (Tek ve Özgül, 2005). Kırım (2001) ise, ilişkisel pazarlamayı "işletmelerin müşterilerinin nasıl farklı olabildiklerini anlaması ve bu farklılıkları göz önüne alarak her bir müşteriye nasıl davranacağına karar vermesi” olarak tanımlamıştır.

Müşteri sadakati, ilişkisel pazarlama ile ulaşılmak istenen temel gaye olmakla birlikte, ilişkisel pazarlama kavramı ile özdeş dahi görülebilmektedir (Sheth, 1996). Hunt, Arnett ve Madhavaram'a (2006) göre ilişkisel pazarlama, müşteri sadakati oluşturma, müşterilerin satın alma sıklığını ve miktarını olumlu yönde etkileme becerisi sebebiyle işletmelerin tercih etmesi gereken bir pazarlama yaklaşımıdır. Ancak, sadık müşterilerin belirli bir işletmeden alım yapmaya devam etmekten çok daha fazlasını yapacakları unutulmamalıdır. Örneğin, işletmeyi başkalarına önerebilecekleri, yeni ürünler için alışveriş yapacakları, ara sıra yapılan hataları affedecekleri ve rakiplerden alışveriş yapmayacakları Harris ve Goode’nin (2004) çalışmasında belirtilmiştir. Bu sonuçlar, müşteri sadakatinin, müşteri tutumu ve davranışları olmak üzere iki boyutu olduğunu gözler önüne sermektedir. Davranış, müşterinin işletme ürünlerini yüksek oranda veya sıklıkta satın alması gibi maddi unsurları içerirken; tutum, müşterinin işletme hakkındaki olumlu görüşleri ile o işletmenin mal ve hizmetlerini devamlı tercih etmeye yatkın olması olarak değerlendirilmektedir (Öz, 2006).

\section{Müşteri Sadakati Programları}

İlişkisel pazarlama bağlamında, müşteri sadakatinin oluşturulması, müşteri sadakat programlarının uygulanması ile gerçekleşmektedir. Sadakat programları, bir markanın pazar teklifine karşı müşterinin tutum ve davranışsal bağlılığını arttırma konusundaki çabası olarak tanımlanabilir (Sharp ve Sharp, 1997). Amerikan Pazarlama Derneği sadakat programlarını "müşterileri ödüllendirmek ve tekrar iş yapmalarını teşvik etmek için bir perakendeci tarafından sunulan daimi teşvikler" şeklinde tanımlamaktadır (Dorotic, Bijmolt ve Verhoef, 2012). Dolayısıyla bu programların temel amacı, mevcut müşteriler hakkında bilgi edinmek, onları elde tutmak için uygun teşvikler sunmak ve böylece müşterilerin alışveriş sıklığını ve miktarını arttırmaktır.

Hussain'in (2016) belirttiği üzere, rekabetçi iş çevresi, işletmeleri müşterilerine çeşitli faydalar sunacakları sürekli bir deneyim yaratan sadakat programlarına yöneltmektedir. Uncles, Dowling ve Hammond (2003), müşteri sadakat programlarının işletmeler açısından iki amacının öne çıktığını belirtmiştir. Birincisi, satın alma veya kullanım seviyelerini ve satın alınan ürün yelpazesini artırarak markanın satış gelirlerini yükseltmektir. İkinci amaç ise, marka ve müşteri arasında bir bağ kurulmasını sağlayarak mevcut müşteri tabanını korumaktır. $\mathrm{Bu}$ amaçların gerçekleştirilmesi ile işletmeler, müşterileri ve eğilimleri hakkında önemli bilgiler edinme, özel müşteri segmentine daha iyi odaklanma ve ürün geri çağırmalarında daha başarılı olma gibi ek avantajlar da elde edebilirler (Çakmak ve Üster, 2013). İşletmelere sağladığı sayısız faydalar neticesinde, müşteri sadakati programları perakendecilik, otel işletmeciliği, havayolu taşımacılığı, araba kiralama ve eğlence gibi sektörlerde yoğun bir şekilde kullanılmaktadır (Lacey ve Sneath, 2006). 
Müşteri sadakati programları sadece işletmelere fayda yaratmakla kalmaz, müşteriler için de uzun dönemde yararlanmak isteyecekleri birçok fayda sunar. Bu faydaları maddi ve maddi olmayan faydalar olarak iki grup altında değerlendirmek mümkündür. Maddi fayda içeren sadakat programları, işletmenin devamlı müşterilerine ekonomik kazançlar sunan indirimler, bonus puanları, kuponlar vb. çeşitli ödüller içermektedir (Özer, 2015). Maddi olmayan faydalar ise, müşterilerin duygularına hitap eden, ayrıcalıklı olduklarını hissetmelerini sağlayan ve hatta statü sembolü olarak görülecek çeşitli hizmet ve sunumları içerir. Bir havayolu işletmesinin chek-in hizmetinde öncelikli sıra imkânı sunması, rezervasyon kolaylı̆̆ı sağlaması, kampanyalardan diğer müşterilerine kıyasla daha önce haberdar etmesi, bilet değişikliği veya iptallerde ayrıcalıklı çözümler geliştirmesi buna örnek gösterilebilir.

Barlow (1996) ile Capizzi ve Furguson (2005), sadakat programlarının sunduğu faydaları sert (hard) veya yumuşak (soft) faydalar olacak şekilde birbirinden ayırmıştır. Sert faydalar içeren sadakat programlarında genellikle indirim ve hediyeler gibi somut unsurlar kullanılırken, yumuşak fayda içeren faydalar ise özel iletişim ve ayrıcalıklı muamele gerektirir. Genellikle, yumuşak fayda içerikli programlar daha duygusal yönelimlidir ve müşterilere bir tanınma hissi vermeye veya onları diğer müşterilere kıyasla özel hissettirmeye çalışır (Barlow, 1996; Harris, 2000). Pazarlama uzmanları, sert ve yumuşak faydaların bir karışımının kullanılmasını savunurken, yumuşak faydaların genellikle daha güçlü bir sadakat artırıcı etki yarattı̆̆ı vurgusunu da yapmaktadırlar (Barlow, 1995).

Müşteri için sunulacak fayda, sadakati teşvik edecek bir değerin sunulmasıyla ilgilidir ve bu değerler farklı koşullarda, farklı müşteriler için değişkenlik gösterebilecektir (Oyman, 2002). Müşterilere sunulacak değerler O'Malley’nin (1998) çalışmasında parasal değer, ödül seçeneklerine yönelik değer, ödüle yönelik arzu değeri, uygunluk değeri ve kolaylık değeri olmak üzere beş başlık altında ele alınmıştır. Oyman’a (2002) göre, nasıl ki işletmeler sadakat oluşturmak için müşterileriyle girişecekleri ilişkilere bir yatırım olarak bakıyorlarsa, müşteriler de bu ilişkiye bir yatırım olarak bakacaklardır. Odabaşı’nın (2000) da belirttiği üzere, müşteriler maddi ve maddi olmayan faydalar neticesinde kalite, tatmin ve yarar elde edecek ve işletmeye olan sadakatini bunlar doğrultusunda şekillendirecektir.

\section{Hipotezler}

Müşteri sadakati programlarının tüketici davranışı üzerindeki etkilerini inceleyen çalışmalar çok sayıda olmakla birlikte, sadakat programlarına yönelik tutum, mağaza memnuniyeti, mağaza sadakati ve satın alma niyeti arasındaki ilişkiyi bir arada inceleyen bir araştırmanın bulunmadığı görülmüştür. Öte yandan, bu ilişkinin, farklı faydalar sunan sadakat programları (örn. maddi/maddi olmayan veya yumuşak/sert faydalar) neticesinde nasıl şekilleneceğini irdeleyen bir çalışmaya da rastlanmamıştır. Nitekim Kendrick (1998), hediye ya da indirim sunan sadakat programlarının, sadece "teşekkür" notu sunan programlara kıyasla daha fazla müşteri sadakati yarattı̆̆ını ortaya koymuştur. Aynı çalışmada, markalı bir ürün hediye etmenin eşit değerde indirim sunmaktan daha fazla sadakat yarattığı da ortaya çıkmıştır. Bir sadakat programına yeni müşteriler çekmek için maddi faydaların daha etkili olduğunu tespit etmiş araştırmalar mevcuttur (örn. Furinto, Pawitra ve Balqiah, 2009; Bojei, Julian, Wel ve 
Ahmed, 2013; Ruzeviciute ve Kamleitner, 2017). Diğer taraftan Melancon, Noble ve Noble (2011), maddi olmayan faydaların tüketici zihninde duygusal değer yarattığı ve uzun vadeli duygusal tepkiler oluşturduğunu belirtmiştir. Bu bulgular, farklı yapıdaki sadakat programlarının farklı sonuçlar doğurabileceğini desteklemektedir. Dolayısıyla aşağıda detayları yer alan her bir hipotez, iki farklı sadakat programı uygulayan Gratis ve Sephora mağazaları için ayrı ayrı test edilmiştir.

Bridson, Evans ve Hickman'ın (2008) çalışmasında, sadakat programlarının mağaza memnuniyetinin önemli belirleyicileri olduğu tespit edilmiştir. Noordhoff, Pauwels ve Schröder (2004), sadakat kartı sahipliği ile mağaza sadakati arasında ilişki olduğunu, ancak bu ilişkiyi kültürel farklılıkların da etkileyeceğini bulmuşlardır. Demoulin ve Zidda (2008) da, sadakat kartı sahiplerinin mağazaya daha sadık olduğunu doğrulamaktadır. Sadakat kartı programlarının satın alma niyeti üzerindeki etkisine ilişkin olarak çalışmalar yine bu ilişkiyi destekleyen bulgular sunmaktadır. Örneğin, Taylor ve Neslin (2005) sadakat programlarının işletme karlılığına katkı sağladığını ortaya koymuştur. Buna ek olarak Liu (2007), sadakat programının satın alma sıklığı ve işlem büyüklüğü üzerinde pozitif bir etki yarattığını tespit etmiştir. Benzer şekilde, Leenheer, van Heerde, Bijmolt ve Smidts (2007) sadakat programı üyeliğinin cüzdan payı (share of wallet) üzerinde küçük de olsa olumlu bir etkisi olduğunu bulmuşlardır. Ancak bu sonuçların, mağaza sadakat programına yönelik tutuma bağlı olarak gerçekleşmesini beklemek daha doğru olacaktır.

Oliver (1980) tutumu, bir tüketicinin bir nesne veya deneyime karşı sahip olduğu duygu, eğilim ya da düşkünlük olarak tanımlamıştır. Fishbein ve Ajzen'e (1975) göre ise tutum, bir bireyin belli bir davranışa yönelik yansıttığı olumlu ya da olumsuz duygulardır. Edinilmiş bir eğilim olarak görülmesi sebebiyle tutumlar dürtüsel bir nitelik taşır, yani tüketicileri belirli bir davranışı benimsemeye itebilirler. Örneğin, Planlı Davranış Teorisine göre davranışsal niyet, tutumun doğrudan bir sonucudur (Fishbein ve Ajzen, 1975; Ajzen, 1991). Bu tanımlardan hareketle, sadakat programlarına yönelik tutumun mağaza memnuniyeti, mağaza sadakati ve satın alma niyeti üzerinde etki oluşturacağı düşünülebilir. Mevcut yazın, bu etkiyi destekleyecek bulgular sunmaktadır.

Tietje’ye (2002) göre, tüketicinin çeşitli ödüller elde etmesi, sadakat programı uygulayan mağaza ile ilgili olumlu duygular geliştirmesine olanak sağlamaktadır. Satın alma deneyimine ilişkin bu duygular, daha büyük bir mağaza memnuniyeti ile sonuçlanarak satın alma niyetini arttırabilir (Price, Arnould ve Tierney, 1995; Oliver, Rust ve Varki, 1997). Taylor ve Neslin'in (2005) de belirttiği üzere, bir sadakat programından elde edilen ödül, ödüllendirilen tüketici mağazaya karşı olumlu duygular beslediği sürece, satın alma davranışını sürekli kılar. Yeniçeri ve Erten (2011) ise, süpermarket tüketicileri üzerine yaptıkları bir araştırmada, sadakat programına yönelik algılarının, mağaza sadakatini etkilediğini savunmuşlardır. Öte yandan, tutumun müşteri sadakatinin oluşmasındaki rolü yadsınamaz, çünkü tekrarlı bir davranışı gerçek sadakat olarak kabul etmek için daha önce olumlu bir tutumun ortaya çıkması gerekmektedir (Day, 1969; Jacoby ve Chestnut, 1978; Assael, 1987; Solomon, 1996). Bununla 
birlikte, Sreejesh, Abhigyan ve Pradhan (2016), mağaza sadakat programına yönelik tutumun mağaza memnuniyetini olumlu etkilediğini tespit etmişlerdir.

Önceki yazına ait bulgular doğrultusunda aşağıdaki hipotezler geliştirilmiştir:

$H_{1}$ : Sadakat programına yönelik tutum, a) Gratis, b) Sephora tüketicilerinin mă̆aza memnuniyetini olumlu yönde etkiler.

$\mathrm{H}_{2}$ : Sadakat programına yönelik tutum, a) Gratis, b) Sephora tüketicilerinin mă̆aza sadakatini olumlu yönde etkiler.

$H_{3}$ : Sadakat programına yönelik tutum, a) Gratis, b) Sephora tüketicilerinin bu mă̆azadan satın alma niyetini olumlu yönde etkiler.

$\mathrm{Bu}$ çalışma kapsamında memnuniyet, müşterinin mağazadan duyduğu memnuniyeti, yani mağaza memnuniyetini, ifade etmektedir. Memnuniyetin genellikle, satın alma ve tüketim sürecinde gerçekleştirilen tüm faaliyetlerin bir çıktısı olarak ele alındığı görülmektedir. Özellikle perakendecilik bağlamında memnuniyet, müşteri sadakati için kilit bir belirleyici olarak tanımlanan süreçler ve çıktılar olarak ifade edilmiştir (Bloemer ve Ruyter, 1998). Johnson ve Fornell (1991), müşteri memnuniyetinin bir ürün veya hizmete yönelik deneyime dayalı genel bir değerlendirme olduğunu öne sürmektedir. Bleomer ve Ruyter (1998) mağaza memnuniyetini, tüketicinin seçtiği mağazadan beklentilerini karşılaması hatta fazlasını alması durumunda yaptığ Özkoç ve Emeç, 2007).

Literatürdeki bulgular, memnuniyetin pazarlama faaliyetlerinin önemli bir sonucu olduğunu ve tutum değişikliği, ağızdan ağıza iletişim, satın alma niyeti, sürekli satın alma ve marka sadakati gibi alım sonrası gerçekleşen unsurlara etki ederek, karar verme ve tüketim arasındaki bağlantıyı sağladığını göstermiştir (Cronin ve Taylor, 1992). Memnuniyet, çoğunlukla sadakatin bir öncüsü olarak kabul edilmektedir (Homburg ve Giering, 2001). Benzer şekilde, müşteri memnuniyetinin müşteri sadakatinin oluşmasına temel teşkil ettiğini belirten Hussain (2016), işletmelerin sürdürülebilir müşteri ilişkileri inşa ederek rekabet avantajı elde etmelerinde, müşteri memnuniyetinin önemli bir rol oynadığını ifade etmiştir. Keh ve Lee'ye (2006) göre, sadakat programları müşteri sadakatini arttırmak için tasarlanmaktadır ve belirli bir memnuniyet eşiği seviyesine ulaşıldığında bu programların etkisi daha belirgin hale gelmektedir. Sadakat kartı programlarının etkisini inceleyen Bridson vd. (2008), mağaza memnuniyetinin mağaza sadakati ile pozitif ilişkili olduğunu, bunun da ötesinde sadakat programı ile mağaza sadakati arasındaki ilişkiye aracılık ettiğini belirtmiştir. Bir diğer çalışmada Eren ve Erge (2012), mağaza memnuniyetinin, mağazanın fiziksel özelliklerinden, satın alma deneyiminden ve uygulanan kampanyalardan oluştuğunu savunmuşlar ve bütün bu faktörlerin müşteriyi memnun edip ihtiyaçlarını karşılayacak seviyeye gelmesi neticesinde mağaza sadakati oluşmasının mümkün olduğunu belirtmişlerdir. Farklı bir alanda da olsa Alkoç (2017)'un üniversite öğrencileri üzerine yaptığı bir araştırmada, üniversiteye duyulan memnuniyet ve öğrenci sadakati arasında doğrudan pozitif bir ilişki olduğu savı desteklenmiştir. Bu bulgulardan hareketle, aşağıdaki hipotez geliştirilmiştir. 
$H_{4}$ : a) Gratis, b) Sephora tüketicilerinin mağaza memnuniyeti mağaza sadakatini olumlu yönde etkiler.

Mağaza memnuniyetinin satın alma niyetiyle sonuçlanması olası bir beklenti olmasına rağmen, Macintosh ve Lockshin (1997) mağaza memnuniyetinin satın alma niyetinde önemli bir etkisi olmadığını tespit etmiş̧tir. Bennett ve Rundle-Thiele (2004), Egan (2000), Mcllroy ve Barnett (2000) da memnuniyetin sadakat için gerekli ancak yeterli bir şart olmadığını öne sürerek, memnun müşterilerin bile başka yerlerde daha iyi değer ve/veya kalite elde etmeleri durumunda tercih değişikliği yapabileceğini belirtmektedir. Öte yandan, Çakmak ve Üster’e (2013) göre, satın alma sırasında ve sonrasında ki ürün ve hizmete duyulan memnuniyet sadakate dönüşür ve sadakat beraberinde tekrar satın almayı getirir. Mevcut yazında, memnuniyetin satın alma niyeti üzerindeki etkisi üzerine birbiri ile çelişen bulgular olduğu görülmektedir. Bu çalışmada, mağaza memnuniyetinin satın alma niyeti üzerinde olumlu etki oluşturacağı varsayılarak aşağıdaki hipotez geliştirilmiştir.

\section{$H_{5}$ : a) Gratis b) Sephora tüketicilerinin mağaza memnuniyeti satın alma niyetini olumlu yönde etkiler.}

Sadakat kavramı ilk başlarda davranısssal bir terim olarak kabul görmüş ve tüketicilerin tekrar satın alma davranışı ile ilişkilendirilerek satışları doğrudan etkilediği düşünülmüştür (Jacoby ve Chestnut, 1978). Sadakat kavramı zaman içerisinde evrim geçirmiş, çünkü sadece davranışı ölçümlemenin sadakati tamamiyle yansıtmadığı anlaşılmıştır (Oliver, 1997). Day (1969) ise sadakati hem davranışsal hem de tutumsal unsurlardan oluşan iki boyutlu bir yapı olarak tanımlamıştır. Benzer bir yaklaşımla Oliver (1997), sadakati "durumsal etkenler veya değişiklik yapmaya iten pazarlama çabalarına rağmen, bir ürün veya hizmeti gelecekte tekrar tercih etmek veya daimi müşteri olmak adına sergilenen derin bir bağ” olarak tanımlamıştır. Bu sadakat tanımı, dışsal etkenlerin varlığını kabul ederken davranışsal ve tutumsal bileşenleri de içermektedir.

Knox ve Denison (2000) mağaza sadakatini tüketicilerin belli bir mağaza veya mağaza zincirlerinin devamlı müşterisi haline gelmesi olarak ifade etmiştir. Bir perakendeciye yönelik sadakati ölçen önceki çalışmalar (örn. Bloemer ve Ruyter, 1998; Wulf ve Odekerken-Schroder, 2003) sadakatin tutum boyutunu adanma ve bağlllık, davranış boyutunu ise satın alma ve ağızdan ağıza iletişim gerçekleş̧irme olarak ele almışlardır. Sadakatin davranışsal bileşeni belirli bir markanın satın alımına odaklandığından (Caruana, 2002), mağaza sadakatinin belli bir perakendeciye yönelik satın alma niyetine yol açması beklenebilir. Nitekim, Ranjbarian, Sanayei, Kaboli ve Hadadian (2012), departman mağazaları tüketicileri üzerine yaptıkları bir araştırmada, mağaza sadakatinin satın alma niyetini olumlu etkilediğini tespit etmişlerdir. Benzer şekilde, Özcan ve Argan (2014) ile Uzunkaya'nın (2016) yaptıkları araştırmalarda, sadakatin satın alma niyetine olumlu etkisi olduğu desteklenmiştir. Bu çalışmalar doğrultusunda aşağıdaki hipotez geliştirilmiştir: 
$H_{6:}$ a) Gratis b) Sephora tüketicilerinin mağaza sadakati, satın alma niyetlerini olumlu yönde etkiler.

Sadakat programına yönelik tutum, mağaza memnuniyeti, mağaza sadakati ve satın alma niyeti arasındaki etkileşimi gösteren araştırma modeli Şekil 1'de sunulmuştur.

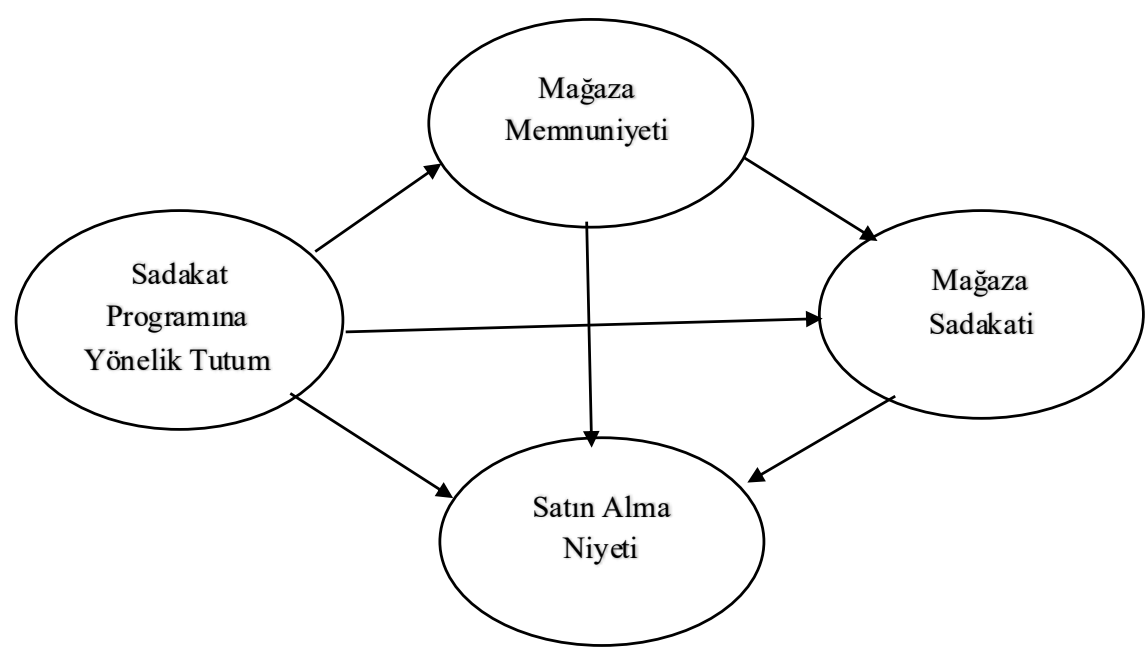

Şekil 1. Araştırma Modeli

\section{Araştırma Yöntemi}

$\mathrm{Bu}$ çalışmada, araştırma sorunu "kozmetik perakendeciliği sektöründeki farklı sadakat programlarının, tüketiciler üzerinde yarattığı etkinin bilinmemesi”dir. Araştırma sorunu doğrultusunda araştırmanın amacı, birbirinden farklı sadakat programı uygulayarak farklı faydalar sunan iki kozmetik perakendecisinin, sadakat programlarını kullanan tüketicilerin, sadakat programına yönelik tutumu, mağaza memnuniyeti, mağaza sadakati ve satın alma niyeti arasındaki etkileşimin incelenmesi olarak belirlenmiştir.

Usta'ya (2012) göre araştırmacı, araştırma sorununu çözmek için izleyeceği yolu (yöntemi) ve kullanacağı teknikleri ayrıntıları ile planlamak zorundadır. Bu çalışmada, nicel araştırma yöntemleri içerisinde deneysel olmayan araştırma yöntemlerinden ilişkisel (korelasyonel) araştırma yöntemi kullanılmıştır. Nicel araştırmalarda, ortaya atılan hipotezlerin test edilmesi ve böylece, tümdengelimsel olarak bilimsel kanunların desteklenmesi ve bilimsel teorilerin güçlendirilmesi hedeflenir (Akarsu ve Akarsu, 2019). Bu sebeple, değişkenler arası ilişkileri çözümleyerek önemli bir olayı anlamak için kullanılan ilişkisel araştırmanın (Akarsu ve Akarsu, 2019), bu çalışma için en uygun yöntem olduğu düşünülmüştür. Araştırmanın amacı doğrultusunda belirlenen araştırma modeli, yapılar arası ilişkilerin tespit edilmesine yönelik geliştirilmiştir. 
Çalışma, bahsi geçen yapılar arasındaki ilişkileri iki kozmetik perakendecisi olan Gratis ve Sephora'yı baz alarak incelemiştir. Bu iki perakendeci özellikle farklı sadakat programları uyguladıkları için seçilmiştir: a) Sephora, tüketicilerin yenilikler, fırsatlar ve kampanyalardan öncelikli olarak haberdar olmalarını, her satın alım sonrası puan kazanma/harcama avantajlarından yararlanma imkânı sağlamakta (“Sephora”, t.y.); b) Gratis, sadakat kartı sahiplerine özel yılın belirli zamanlarında belirli ürünlerde indirim sunmaktadır (“Gratis”, t.y.). Literatürde yapılan sadakat programı sınıflandırmaları dikkate alındığında, Sephora’nın sert ve yumuşak faydaları bir arada kullandığı, Gratis'in ise sadece sert faydalar doğrultusunda tüketicilerine hizmet sağladığı görülmektedir. 2009 yılından beri Türkiye kişisel bakım sektöründe yer alan Gratis, bugün 79 ilde 605 mağazayla hizmet vermektedir (Kozmetik Dünyası, 2019). Türkiye pazarına 2007 yılında giriş yapan Sephora ise, 12 yılda 44 mağazaya ulaşmıştır (Kozmetik Dünyası, 2019).

Araştırmada kullanılan yapılara ait ölçekler, daha önceki akademik araştırmalardan alınmıştır. Sadakat programına yönelik tutum (15 ifade), mağaza memnuniyeti (10 ifade) ve mağaza sadakati (8 ifade) Bridson vd.'nin (2008) çalışmasından adapte edilirken, satın alma niyeti (3 ifade) Macintosh ve Lockshin’in (1997) araştırmasından alınmıştır.

Araştırmanın evrenini belirlenmiş olan perakendecilerin sadakat kartlarına sahip olan ve İstanbul'da yaşayan tüketiciler oluşturmaktadır. Örneklemde yer alan katılımcılar, zaman ve bütçe kısıtı sebebiyle tesadüfi olmayan örnekleme yöntemlerinden birisi olan kolayda örnekleme yöntemi ile belirlenmiştir. Katılımcılar, araştırmacıların kolaylıkla ulaşabilecekleri ve anket sorularını titizlikle cevaplayacaklarını düşündükleri tanıdıkları arasından seçilmiştir. Veri toplama yöntemi olarak, Google Forms vasıtasıyla hazırlanan çevrimiçi anket formu kullanılmış ve anket linki katılımcıların e-posta adreslerine yollanmıştır. Veri toplama süreci 2019 yılı Nisan-Mayıs ayları arasında gerçekleşmiştir. 238 kişiye yollanan anket, 201 kişi tarafından cevaplanmış, ancak bir katılımcının hangi perakendecinin sadakat kartını kullandığını belirtmemesi sebebiyle, verdiği cevaplar araştırmaya dâhil edilmemiştir. Bunun neticesinde, örneklem içerisinde 200 katılımcı yer almıştır. Örneklemin çoğunluğunu erkekler oluşturmaktadır (\%71,5). \%80,5'in 15-25 yaş aralığında olduğu örneklemin \%84'ü üniversite mezunudur. \%82'si bekâr olan katılımcıların \%65'i aylık 5000 TL ve üzeri hanehalkı gelirine sahiptir. Ve son olarak, katılımcıların \%36'sı Gratis sadakat kartına sahipken, \%64’ü Sephora karta sahiptir. Örnekleme ait detaylı bilgiler Tablo 1'den incelenebilir. 
Tablo 1. Demografik Özellikler

\begin{tabular}{|c|c|c|c|c|c|c|c|}
\hline \multicolumn{2}{|c|}{ Demografik Özellikler } & \multirow{2}{*}{\begin{tabular}{|l|} 
Sıklık \\
57 \\
\end{tabular}} & \multirow{2}{*}{$\begin{array}{l}\text { Yüzde } \\
28,5\end{array}$} & \multicolumn{2}{|c|}{ Demografik Özellikler } & \multirow{2}{*}{$\begin{array}{l}\text { Sıklık } \\
19\end{array}$} & \multirow{2}{*}{\begin{tabular}{|l} 
Yüzde \\
9,5
\end{tabular}} \\
\hline \multirow{2}{*}{ Cinsiyet } & Kadın & & & \multirow{5}{*}{ Gelir } & $<1500 \mathrm{TL}$ & & \\
\hline & Erkek & 143 & 71,5 & & 1501-5000 TL & 1 & 25,5 \\
\hline \multirow{3}{*}{ Yaş } & $15-25$ & 161 & 80,5 & & 5001-10000 TL & 59 & 29,5 \\
\hline & $26-35$ & 30 & 15,0 & & 10001-15000 TL & 46 & 23,0 \\
\hline & $36-60$ & 9 & 4,5 & & $15001-20000 \mathrm{TL}$ & 25 & 12,5 \\
\hline \multirow{2}{*}{ Medeni Durum } & Evli & 36 & 18,0 & \multirow{8}{*}{ Meslek } & Serbest & 2 & 1,0 \\
\hline & Bekâr & 164 & 82,0 & & \begin{tabular}{|l} 
Ev Hanımı \\
\end{tabular} & 6 & 3,0 \\
\hline \multirow{4}{*}{ Eğitim Seviyesi } & İlköğretim & 1 & 0,5 & & İşçi & 2 & 1,0 \\
\hline & Lise & 4 & 2,0 & & Memur & 9 & 4,5 \\
\hline & Üniversite & 168 & 84,0 & & Özel Sektör & 35 & 17,5 \\
\hline & $\begin{array}{l}\text { Yüksek } \\
\text { Lisans }\end{array}$ & 27 & 13,5 & & Öğrenci & 138 & 69,0 \\
\hline \multirow{2}{*}{ Sadakat Kartı } & Gratis & 128 & 36 & & İşsiz & 8 & 4,0 \\
\hline & Sephora & 72 & 64 & & & & \\
\hline
\end{tabular}

Araştırma modeli elde edilen veriler doğrultusunda "Kısmi En Küçük Kareler Yöntemine Dayalı Yapısal Eşitlik Modellemesi (PLS-SEM)” ile Smart-PLS3 programı kullanılarak analiz edilmiştir. PLS-SEM, örneklem büyüklügü̈ne bakılmaksızın küçük örneklemlerde dahi istatistiksel analizleri yerine getirme gücü olan bir yöntem (Hair, Sarstedt, Ringle ve Mena, 2012) olduğu için tercih edilmiştir. İki aşamalı bir yaklaşımın kullanıldığı analiz sürecinde, öncelikle ölçüm modeli incelenerek yapıların geçerliliği ve güvenilirliği belirlenmiş, daha sonra da yapısal model değerlendirilerek araştırma modeli test edilmiş ve hipotezler eş zamanlı test edilmiştir (Anderson ve Gerbing, 1988). Araştırma modeli hem Gratis, hem de Sephora için ayrı ayrı test edildiği için Çoklu Grup Analizi kullanılmıştır.

\section{Bulgular}

\section{Ölçüm Modelinin Değerlendirilmesi}

Ölçüm modelini değerlendirmek için güvenilirlik ve geçerlilik değerleri ele alınmıştır. Yapılara ait iç güvenilirlik, Cronbach Alpha (CA) ve Bileşik Güvenilirlik (CR) değerleri ile incelenmiştir. Yakınsaklık geçerliliği için Ortalama Açıklanan Varyans (AVE) değerlerine başvurulmuştur. Son olarak, ayrışma geçerliliği için ise Fornelle Larcker (FL) ve Heterotrait-Monotrait (HTMT) kriterleri kullanılmıștır.

İlk ölçüm modeli sonuçları her ne kadar bütün yapıların güvenilirliği için beklenen değerlerde çıksa da, sadakat programına yönelik tutum ölçeğine yönelik yakınsaklık ve ayrışma geçerliliği olması gereken değerlerin altında seyretmiştir. Bu ölçeğe ait ifadelerin yük değerlerine bakıldığında üç ifadenin yük değerinin 0.5'in altında olduğu görülmüş ve Hair, Black, Babin ve Anderson'ın (2010) önerisiyle bunlar ölçekten çıkarılmıştır. Tablo 2'de, çıkarılan ifadelerin üzeri çizili olarak gösterilmiş olup, onların çıkarılması sonucunda elde edilen AVE, CR ve CA değerleri belirtilmiştir. Aynı tabloda diğer yapılara ait güvenilirlik ve geçerlilik sonuçları da yer almaktadır. Görüldügü üzere, her bir yapının yüksek bir iç güvenilirlik seviyesine işaret eden, 
0.852 ila 0.940 arasında değișen ve 0.7 'den büyük bir CA değeri vardır (Nunnally, 1978). Buna ek olarak, tüm CR değerleri 0,8'in üzerinde ve 0,911 ile 0,949 arasında değişmektedir ki bu, yapıların iyi bir güvenilirliğe sahip olduğunu göstermektedir (Hair vd., 2017). Her ifade için, mutlak standartlaştırılmış birinci dereceden yük değerlerinin çoğu 0.7'den yüksektir ve 0.667 ila 0.936 arasında değişmektedir (Fornell ve Larcker, 1981). Dolayısıyla, modeldeki yapıların iç güvenilirliğinin sağlandığı görülmektedir.

Tablo 2. Ölçüm Modeli Sonuçları

\begin{tabular}{|c|c|c|c|c|c|}
\hline \multirow[t]{2}{*}{ Yapl } & \multirow[t]{2}{*}{ İfade } & \multirow{2}{*}{$\begin{array}{l}\text { Yük } \\
\text { Değeri }\end{array}$} & \multirow[t]{2}{*}{$\overline{\mathrm{AVE}}$} & \multicolumn{2}{|c|}{ Güvenilirlik Değerleri } \\
\hline & & & & $\begin{array}{l}\text { Bileşik } \\
\text { Güvenilirlik } \\
\text { (CR) }\end{array}$ & C.Alpha \\
\hline \multirow{15}{*}{$\begin{array}{l}\text { Sadakat } \\
\text { Programına } \\
\text { Yönelik } \\
\text { Tutum (SPT) }\end{array}$} & 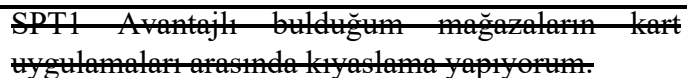 & 0.421 & \multirow[t]{15}{*}{0.602} & \multirow[t]{15}{*}{0.947} & \multirow[t]{15}{*}{0.939} \\
\hline & $\begin{array}{l}\text { SPT2 Mağaza kartı kullanmaya başladığımdan } \\
\text { itibaren kazançlı çıktığımı düşünüyorum. }\end{array}$ & 0.871 & & & \\
\hline & $\begin{array}{l}\text { SPT3 Mağaza kartı uygulaması olan firmaların daha } \\
\text { profesyonel olduğunu düşünüyorum. }\end{array}$ & 0.719 & & & \\
\hline & $\begin{array}{l}\text { SPT4 Mağaza kartının cüzdanımda olması, alışveriş̧ } \\
\text { yapmaya karar verdiğimde bu mağazanın ilk olarak } \\
\text { aklıma gelmesini sağlıyor. }\end{array}$ & 0.747 & & & \\
\hline & $\begin{array}{l}\text { SPT5 Mağaza kartına özel yapılan kampanyalardan } \\
\text { sıklıkla yararlanırım. }\end{array}$ & 0.667 & & & \\
\hline & $\begin{array}{l}\text { SPT6 Mağaza kartı alışverişlerimde indirim } \\
\text { sağlıyor. }\end{array}$ & 0.836 & & & \\
\hline & $\begin{array}{l}\text { SPT7 Mağaza kartı puan biriktirmeme ve bu } \\
\text { puanları kullanmama olanak sağllyor. }\end{array}$ & 0.811 & & & \\
\hline & $\begin{array}{l}\text { SPT8 Mağaza kartı kampanya ve çekilişlere } \\
\text { katılmamı sağlıyor. }\end{array}$ & 0.804 & & & \\
\hline & $\begin{array}{l}\text { SPT9 Mağaza kartı, hediye uygulamalardan } \\
\text { yararlanmamı sağliyor. }\end{array}$ & 0.753 & & & \\
\hline & $\begin{array}{l}\text { SPT10 Mağaza kartı kullanmaya başladığımdan } \\
\text { itibaren kazançlı çktığımı düsünüyorum. }\end{array}$ & 0.835 & & & \\
\hline & $\begin{array}{l}\text { SPT11 Anmda ödüllendirme-sistemli sadakat } \\
\text { kartlart beni-tkiler. }\end{array}$ & 0.405 & & & \\
\hline & $\begin{array}{l}\text { SPT12 Kullandığım markanın sadakat kartı satın } \\
\text { alma davranıșımı etkiler. }\end{array}$ & 0.712 & & & \\
\hline &  & 0.386 & & & \\
\hline & $\begin{array}{l}\text { SPT14 Düzenli olarak markanın kendi ürünlerinde } \\
\text { \% indirim sağladığı sadakat kartları beni daha çok } \\
\text { etkiler. }\end{array}$ & 0.683 & & & \\
\hline & $\begin{array}{l}\text { SPT15 Kartın tüketiciye avantaj sağladığına } \\
\text { inanıyorum. }\end{array}$ & 0.843 & & & \\
\hline
\end{tabular}


Tablo 2. Ölçüm Modeli Sonuçları (Devamı)

\begin{tabular}{|c|c|c|c|c|c|}
\hline \multirow{10}{*}{$\begin{array}{l}\text { Mağaza } \\
\text { Memnuniyeti } \\
(\mathrm{MM})\end{array}$} & $\begin{array}{l}\text { MM1 Bu mağazanın ürünleri, diğer mağazaların } \\
\text { ürünlerine kıyasla beni daha çok memnun ediyor. }\end{array}$ & 0.856 & \multirow[t]{10}{*}{0.650} & \multirow[t]{10}{*}{0.949} & \multirow[t]{10}{*}{0.940} \\
\hline & $\begin{array}{l}\text { MM2 Bu mağaza siradan müşterilerine oranla, } \\
\text { sürekli müșterilerine daha iyi hizmet vermektedir. }\end{array}$ & 0.828 & & & \\
\hline & $\begin{array}{l}\text { MM3 Başka bir perakendeciye geçmeyi asla } \\
\text { düşünmem. }\end{array}$ & 0.836 & & & \\
\hline & $\begin{array}{l}\text { MM4 Eğer bu mağaza kapatılırsa, kozmetik } \\
\text { alanında yeni bir mağaza bulmam zor olur. }\end{array}$ & 0.851 & & & \\
\hline & $\begin{array}{l}\text { MM5 Bu mağazanın ürün çeşitliliğinin fazla olması } \\
\text { beni memnun ediyor. }\end{array}$ & 0.759 & & & \\
\hline & $\begin{array}{l}\text { MM6 Kullandığım markanın sadık müşterilerine } \\
\text { yönelik uyguladığı kampanyalar başarılı değildir. }\end{array}$ & 0.707 & & & \\
\hline & $\begin{array}{l}\text { MM7 Bu mağazanın çalışanları bana istediğim anda } \\
\text { hemen yardımcı oluyor. }\end{array}$ & 0.781 & & & \\
\hline & $\begin{array}{l}\text { MM8 } \mathrm{Bu} \text { mağazada ürünler her şeyi rahatça } \\
\text { bulabileceğim sekilde sinıflandırılmıstır. }\end{array}$ & 0.806 & & & \\
\hline & $\begin{array}{l}\text { MM9 Bu mağazadan alışveriş yapıyorum çünkü } \\
\text { rakiplerine göre daha iyi ürünler sunuyor. }\end{array}$ & 0.815 & & & \\
\hline & $\begin{array}{l}\text { MM10 Bu mağazadan alışveriş } \\
\text { müşsterilerine değer veriyor olması önemli bir } \\
\text { etkendir. }\end{array}$ & 0.809 & & & \\
\hline \multirow{8}{*}{$\begin{array}{l}\text { Mağaza } \\
\text { Sadakati } \\
\text { (MS) }\end{array}$} & $\begin{array}{l}\text { MS1 Kendimi bu mağazanın düzenli bir müşterisi } \\
\text { gibi hissediyorum. }\end{array}$ & 0.863 & \multirow[t]{8}{*}{0.686} & \multirow[t]{8}{*}{0.946} & \multirow[t]{8}{*}{0.934} \\
\hline & MS2 Sürekli bu mağazadan alışveriş yaparım. & 0.880 & & & \\
\hline & $\begin{array}{l}\text { MS3 Kozmetik kategorisinde alışveriş yapacaksam, } \\
\text { ilk tercihim bu mağaza olur. }\end{array}$ & 0.820 & & & \\
\hline & $\begin{array}{l}\text { MS4 } \mathrm{Bu} \text { perakendeci ile gelecekte daha fazla iş } \\
\text { yapmayı planlıyorum }\end{array}$ & 0.829 & & & \\
\hline & MS5 Kendimi bu mağazaya bağlı hissetmiyorum. & 0.740 & & & \\
\hline & $\begin{array}{l}\text { MS6 Kartım olan mağazadan daha çok alışveriş } \\
\text { yapmaya başladım. }\end{array}$ & 0.819 & & & \\
\hline & $\begin{array}{l}\text { MS7 Bu mağazanın fiyatları biraz daha yüksek olsa } \\
\text { dahi bu mağazadan alışveriş yapmayı tercih } \\
\text { ediyorum. }\end{array}$ & 0.875 & & & \\
\hline & $\begin{array}{l}\text { MS8 Başka bir mağazada indirim olsa bile yine bu } \\
\text { mağazay1 tercih ederim. }\end{array}$ & 0.789 & & & \\
\hline \multirow[t]{3}{*}{$\begin{array}{l}\text { Satın Alma } \\
\text { Niyeti (SAN) }\end{array}$} & $\begin{array}{l}\text { SAN1 İtiyacım olmasa bile kartıma özel indirim } \\
\text { varsa alışveriş yaparım. }\end{array}$ & 0.845 & \multirow[t]{3}{*}{0.774} & \multirow[t]{3}{*}{0.911} & \multirow[t]{3}{*}{0.852} \\
\hline & $\begin{array}{l}\text { SAN2 Mağaza kartına tanınan indirim ve firsatlar } \\
\text { satın alma niyetimi etkiler. }\end{array}$ & 0.936 & & & \\
\hline & $\begin{array}{llll}\text { SAN3 Öümüzdeki aylarda } & \text { mağaza } & \text { kartımı } \\
\text { kullanarak alıșveriș yapacağım. } & & \end{array}$ & 0.855 & & & \\
\hline
\end{tabular}

Tüm yapıların AVE değerleri 0,5 eşik değerinin üzerindedir ve bu da yakınsaklık geçerliliğinin sağlandığını göstermektedir (Fornell ve Larcker, 1981). Ayrışma geçerliliğini değerlendirmek için hem FL hem de HTMT kriterleri kullanılmıştır. FL kriterine göre, eğer bir yapıya ait AVE'nin karekökü diğer yapılar ile olan korelasyonundan daha yüksek ise, o zaman yapıların ayrışma geçerliliği vardır (Fornell ve Larcker, 1981). Tablo 3 'ten görülebileceği gibi, bu kural araştırma modelinin tüm yapıları için sağlanmıştır. HTMT’ye göre ise, tüm HTMT değerleri, birbirinden farklı olması beklenen yapılar için 0,85'ten düşük olmalıdır (Henseler, Ringle ve Sarstedt, 2014). Tablo 4'e bakıldığında, tüm değerlerin belirtilen eşikten düşük olduğu ve ayrışma geçerliliğinin bir kez daha teyit edildiğini göstermektedir. 
Tablo 3. Fornell-Larcker Kriteri

\begin{tabular}{|c|c|c|c|c|}
\hline & SPT & SAN & MM & MS \\
\hline SPT & 0.776 & & & \\
\hline SAN & 0.748 & 0.880 & & \\
\hline MM & 0.772 & 0.751 & 0.806 & 0.828 \\
\hline MS & 0.714 & 0.815 & 0.769 & \\
\hline \multicolumn{5}{|l|}{ SPT=Sadakat Programına Yönelik Tutum, SAN= Satın Alma Niyeti, MM=Mağaza Memnuniyeti, MS= Mağaza Sadakati }
\end{tabular}

Tablo 4. Heterotrait-Monotrait Ratio (HTMT)

\begin{tabular}{|r|c|c|c|c|}
\hline & SPT & SAN & MM & MS \\
\hline SPT & & & & \\
\hline SAN & 0.833 & & & \\
\hline MM & 0.817 & 0.838 & & \\
\hline MS & 0.845 & 0.812 & 0.825 & \\
\hline
\end{tabular}

Yukarıda belirtilen sonuçların istatistiksel olarak anlamlı olup olmadığını incelemek için bootstrap yöntemi 5000 alt örneklemle uygulanmıştır (Hair vd., 2017). Sonuçlar, CA, CR ve AVE değerlerinin $\mathrm{p}<0.01$ seviyesinde anlamlı olduğunu göstermektedir. Ayrışma geçerliliği sonuçları 1'den anlamlı derecede farklıdır, çünkü Güven Aralığı [\% 2,5,\% 97,5] arasındaki değerlerin hiçbiri 1 değildir (Hair vd., 2017). Bu nedenle, tüm yapıların kavramsal olarak farklı olduğu ve ayrışma geçerliliği, yakınsaklık geçerliliği ve iç güvenilirliği bu değerlendirmeler sonucunda tespit edilmiştir.

Ölçüm modeline yönelik son değerlendirme, PLS modellemesinde tek model uygunluğu kriteri olan Satandardize Edilmiş Uyum İyilik İndeksi'dir (SRMR) (Henseler, Hubona ve Ray, 2016). Hair vd. (2017), 0,08'den düşük bir SRMR değerinin kovaryans temelli SEM modelleri için uygun olduğunu düşünmektedir. Bu çalışmada, SRMR'nin 0.077 olduğu görülmüştür ve PLSSEM analizine uygun bir model oluşturulduğuna kanaat getirilmiştir (Henseler vd., 2016).

\section{Yapısal Modelin Değerlendirilmesi}

Yapılara ait ölçeklerin güvenilir ve geçerli olduklarını teyit ettikten sonra, yapısal model değerlendirmesi bir sonraki adım olarak ele alınmalıdır. Bu, modelin tahmin gücünü ve yapılar arasındaki ilişkileri incelemeyi içerir (Hair vd., 2017). Ancak yapısal modeli değerlendirmeden önce, yol katsayılarında yanlılık olmadığından emin olmak için yapısal model yapıları eşdoğrusallık (colliniearity) açısından incelenmelidir (Hair vd., 2017). Çoklu doğrusallığa sahip olmamak adına, her bir yapı kümesi arasındaki VIF değerleri 3'ten düşük olmalıdır (Hair vd., 2017). Araştırma modeli göz önüne alındığında, tüm VIF değerlerinin 3'ün altında olduğu ve bu nedenle eşdoğrusallık sorununun olmadığı görülmüştür.

Modelin tahmin gücü $\mathrm{R}^{2}$ değerleri ile ölçülmektedir. Tablo 5 'te yapısal modelin $\mathrm{R}^{2}$ ve $f^{2}$ değerleri yer almaktadır. Satın Alma Niyetine ait $\mathrm{R}^{2}$ değeri $0.688^{\prime}$ dir ve bu, modeldeki bütün diğer yapıların satın alma niyetine ait varyansın \%68.8'ini açıkladığını göstermektedir. Öte yandan, 
mağaza sadakatinin ve mağaza memnuniyetinin $\mathrm{R}^{2}$ değerleri sırasıyla 0.806 ve 0.596 'dır. Hair vd.'ye (2012) göre, tüketici davranışı bağlamında bu $\mathrm{R}^{2}$ değerleri oldukça yüksektir.

$f^{2}$ olarak belirtilen etki büyüklüğü, bir yapının endojen bir yapı üzerindeki etkisini değerlendirmek için ele alınmaktadır (Hair vd., 2017). Cohen'e (1998) göre, 0.02, 0.15 ve $0.35 f^{2}$ değerleri, yordayıcı gizil değişkenin sırasıyla küçük, orta veya büyük etki büyüklügüne sahip olduğunu gösterir. Buna göre, Tablo 5 incelendiğinde, satın alma niyetine yönelik etki büyüklüğü en fazla mağaza sadakatinden gelmekte $\left(f^{2}=0.175\right)$, onu sadakat programına yönelik tutum $\left(f^{2}=0.054\right)$ takip etmekte ve bu iki yapının büyük bir etki büyüklüğüne sahip olduğu görülmektedir. Öte yandan mağaza memnuniyetinin $\left(f^{2}=0.010\right)$ etki büyüklüğü küçüktür. Mağaza sadakatini yordayan iki yapı içerisinde ise en büyük etkiyi 0.735 ile mağaza memnuniyetinin oluşturduğu görülmektedir.

Tablo 5. $R^{2}$ ve f Değerleri

\begin{tabular}{|r|l|l|l|}
\hline & $\begin{array}{l}\text { MM } f^{2} \\
\left(\mathrm{R}^{2}=0.596\right)\end{array}$ & $\begin{array}{l}\text { MS f } \\
\left(\mathrm{R}^{2}=0.806\right)\end{array}$ & $\begin{array}{l}\text { SAN } f^{2} \\
\left(\mathrm{R}^{2}=0.688\right)\end{array}$ \\
\hline SPT & 1.472 & 0.264 & 0.054 \\
\hline MM & & 0.735 & 0.010 \\
\hline MS & & 0.175 \\
\hline \\
SPT=Sadakat Programina Yönelik Tutum, SAN= Satın Alma Niyeti, MM=Mağaza Memnuniyeti, \\
MSağaza Sadakati
\end{tabular}

\section{Hipotez Testi}

Hipotezleri test etmek ve yol katsayılarının istatistiksel anlamlılı̆̆ını değerlendirmek için bootstrap yöntemi kullanılmıştır. PLS-SEM dağılımın normal olması varsayımına dayanmaz, ancak hipotezler ile test edilen ilişkilerin istatistiksel olarak anlamlı olup olmadıklarını değerlendirmek için standart hataların ve t-istatistiklerinin elde edildiği parametrik olmayan ve bootstrap olarak adlandırılan bir yöntem uygular (Hair vd., 2017). Bu çalışmada t-istatistiklerini elde etmek için 200 katılımcıdan elde edilen veriler 5000 altörnekleme ile bootstrap yöntemine tabii tutulmuştur.

Hipotezleri test etmek, yol katsayılarını belirlemek ve bu sonuçları hem Gratis hem de Sephora müşterileri için ayrı ayrı değerlendirmek maksadıyla Çoklu Grup Analizine (Multi Grup Analysis-MGA) başvurulmuştur. Bulgular Tablo 6'da yer almaktadır.

Hipotezler sırasıyla değerlendirmeye alındığında, sadakat programına yönelik tutum tüketicilerin mağaza memnuniyetini olumlu yönde etkiler şeklinde ifade edilen $\mathrm{H}_{1}$ 'in hem Gratis hem de Sephora için desteklendiği görülmektedir. Her iki perakendeciye ait yol katsayıları 0.05 düzeyinde anlamlı olmakla birlikte, Sephora sadakat programını kullanan tüketicilerde daha fazla mağaza memnuniyeti ortaya çıktığı görülmektedir (Gratis=0.601, Sephora $=0.876$ ). Sadakat programına yönelik tutum tüketicilerin mağaza sadakatini olumlu yönde etkiler olarak belirtilen $\mathrm{H}_{2}$ 'de de benzer sonuçlar elde edilmiştir. Yine her iki perakendeciye ait yol katsayıları 0.05 düzeyinde anlamlıdır ve Sephora sadakat programını kullanan tüketicilerde daha fazla mağaza sadakati oluştuğu tespit edilmiştir (Gratis=0.310, 
Sephora=0.737). $\mathrm{H}_{3}$ için ise farklı bir durum söz konusudur: Sadakat programına yönelik tutum tüketicilerin satın alma niyetini olumlu yönde etkiler şeklinde oluşturulan bu hipotez Gratis için desteklenirken Sephora için reddedilmiştir (Gratis=0.242, Sephora=0.354). $\mathrm{H}_{4}$ hipotezi için de benzer sonuç elde edildiği görülmektedir. Mağaza memnuniyeti, mağaza sadakatini olumlu yönde etkiler ifadesine yer veren bu hipotez Gratis için desteklenmiş (Gratis=0.590) ancak Sephora için reddedilmiştir (Sephora=0.235). Mağaza memnuniyeti, satın alma niyetini olumlu yönde etkiler olarak ifade edilen $\mathrm{H}_{5}$ hipotezi ise her iki perakendeci için reddedilmiştir (Gratis=0.152, Sephora=0.026). Son olarak, $\mathrm{H}_{6}$ hipotezi Gratis için desteklenmiş (Gratis=0.399) ancak Sephora için reddedilmiştir (Sephora=0.559). Bir başka deyişle, mağaza sadakati Gratis için satın alma niyeti oluştururken, aynı durum Sephora için gerçekleşmemektedir.

Tablo 6. Yol Katsayıları ve PLS-MGA Sonuçları

\begin{tabular}{|c|c|c|c|c|c|c|c|}
\hline & \multicolumn{3}{|c|}{ Yol Katsayıları } & \multirow{2}{*}{$\begin{array}{c}\text { Yol } \\
\text { Katsayıları- } \\
\text { Fark (Gratis- } \\
\text { Sephora) }\end{array}$} & \multirow{2}{*}{$\begin{array}{l}\text { p-değeri } \\
\text { (Gratis- } \\
\text { Sephora) }\end{array}$} & \multicolumn{2}{|l|}{ Hipotezler } \\
\hline & Orijinal & Gratis & Sephora & & & Gratis & Sephora \\
\hline H1:SPT $\rightarrow$ MM & $0.772 *$ & $0.601^{*}$ & $0.876^{*}$ & 0.275 & 0.001 & Desteklendi & Desteklendi \\
\hline H2:SPT $\rightarrow$ MS & $0.356^{*}$ & $0.310^{*}$ & $0.737^{*}$ & 0.427 & 0.003 & Desteklendi & Desteklendi \\
\hline H3:SPT $\rightarrow$ SAN & $0.228^{*}$ & $0.242^{*}$ & 0.354 & 0.112 & 0.708 & Desteklendi & Reddedildi \\
\hline H4:MM $\rightarrow$ MS & $0.594^{*}$ & $0.590^{*}$ & 0.235 & 0.355 & 0.012 & Desteklendi & Reddedildi \\
\hline H5:MM $\rightarrow$ SAN & 0.114 & 0.152 & 0.026 & 0.126 & 0.469 & Reddedildi & Reddedildi \\
\hline H6:MS $\rightarrow$ SAN & $0.719^{*}$ & $0.399^{*}$ & 0.559 & 0.160 & 0.536 & Desteklendi & Reddedildi \\
\hline
\end{tabular}

SPT=Sadakat Programına Yönelik Tutum, SAN= Satın Alma Niyeti, MM=Măgaza Memnuniyeti, MS= Măgaza Sadakati

\section{Sonuç}

Günümüz iş dünyasında rekabet, her alanda olduğu gibi kozmetik perakendeciliğinde de etkisini hissettirmektedir. Ülkemizde faaliyet gösteren Sephora, Gratis, Rossman, Watsons vb. kozmetik perakendecileri çeşitli sadakat programları uygulamaya yönelten bu durum neticesinde, tüketici bağlılığı ve satın alma niyeti oluşturmak hedeflenmektedir. Ancak gerçekte, sadakat programlarının bu etkileri yaratıp yaratmayacağı bilinmemektedir. Bu çalışmada, mevcut yazındaki boşluğun doldurulması hedeflenerek, tüketicilerin sadakat programlarına yönelik tutumu, mağaza memnuniyeti, mağaza sadakati ve satın alma niyeti arasındaki etkileşim incelenmiştir. Bu maksatla, farklı sadakat programı uygulamakta olan iki kozmetik perakendecisi - Gratis ve Sephora - seçilerek, bu iki perakendeciden birisinin sadakat programını kullanan tüketiciler nezdinde ilgili yapıların birbirileriyle olan ilişkisine bakılmıştır. Gratis ve Sephora'nın seçilme nedeni, her iki perakendecinin farklı sadakat programı uygulamasıdır. Sephora, hem maddi/sert (indirim sağlama, puan toplama, ödül/hediye/kupon dağıtımı vb.) hem de maddi olmayan/yumuşak faydalar (tüketicilerin kendilerini özel/ayrıcalıklı hissetmelerini sağlayacak faydalar) sunan bir sadakat programına sahipken, Gratis sadece maddi/sert faydalar sunmaktadir. 
Araştırmada önerilen araştırma modeli, 200 katılımcıdan elde edilen verilerle "Kısmi En Küçük Kareler Yöntemine Dayalı Yapısal Eşitlik Modellemesi” kullanılarak test edilmiştir. Hipotezler hem Gratis hem de Sephora kullanıcıları için ayrı ayrı değerlendirildiğinden ötürü "Çoklu Grup Analizi” ne de başvurulmuştur. Bulgulara göre, hipotezlerin çoğu Gratis için desteklenmiştir: Altı hipotezin beşi Gratis için destek bulmuş, Sephora için sadece iki tanesi kabul edilmiştir.

Önceki çalışmalar, sadakat programına yönelik tutumun mağaza memnuniyeti (Price vd., 1995; Oliver vd., 1997; Sreejesh vd., 2016), mağaza sadakati (Day, 1969; Jacoby ve Chestnut, 1978; Assael, 1987; Solomon, 1996; Yeniçeri ve Erten, 2011) ve satın alma niyeti (Price vd., 1995; Oliver vd., 1997; Taylor ve Neslin, 2004) üzerinde olumlu etkiler yaratacağına dair destekleyici sonuçlar sunmaktadır. Ancak bu çalışmada elde edilen bulgular, sadakat programında tüketicilere sunulan faydalar bazında beklenen etkilerin değişebileceğine işaret etmektedir. Sadakat kartı sahiplerine sadece sert fayda (indirim) sunarak değer yaratan Gratis'in sadakat programına yönelik tutum, incelenen bütün yapılar üzerinde olumlu etki oluşturmuştur. Diğer taraftan, hem sert hem de yumuşak fayda (puan kazanma ve kart sahiplerine yenilikler, firsatlar ve kampanyalar hakkında öncelikli bildirim) sunan Sephora için satın alma niyeti ortaya çıkmazken, mağaza memnuniyeti ve mağaza sadakati üzerinde Gratis'e göre daha yüksek bir etki oluşmaktadır. Bu bulgu, Barlow’un (1995) çalışmasında belirtilen, yumuşak faydaların genellikle daha güçlü bir sadakat artırıcı etki yarattığı ancak, sert ve yumuşak faydaların bir karışımının kullanılması gerektiği yönündeki öneri ile örtüşmektedir. Oyman’ın (2002) da belirttiği üzere, müşteri için sunulacak fayda, sadakati teşvik edecek bir değerin sunulmasıyla ilgilidir. $\mathrm{Bu}$ araştırma neticesine göre, kozmetik perakendecileri sadakat arttırmayı hedefliyorlarsa müşteri değerini maksimize edecek faydalar bütününü belirlemelidir. Öte yandan, hem sert hem de yumuşak faydaları bir arada sunmasına rağmen, Sephora'nın sadakat programına yönelik tutumun satın alma niyeti oluşturmaması merak konusudur. Bu noktada, "bir sadakat programından elde edilen ödül, ödüllendirilen tüketici mağazaya karşı olumlu duygular beslediği sürece, satın alma davranışını sürekli kılar” açıklamasını yapan Taylor ve Neslin'e (2005) hak vermek gerekebilir. Özellikle satın alma niyetinin oluşmasında sadece sadakat programlarının değil diğer pazarlama çabalarının da varlığının etkili olduğu göz önünde bulundurulmalıdır. Dolayısıyla, bu çalışmadan elde edilen bulgular neticesinde pazarlama yöneticilerine, sadakat programından beklenen etkiler doğrultusunda tüketicilere sunulacak faydaların belirlenmesi gerektiği önerisi yapılabilir. Eğer satışlar üzerindeki etki öncelikli ise, tüketicilerin alışverişlerinden elde ettikleri indirim gibi anlık sert faydalar kullanılabilir. Diğer yandan, sadakat programının satın alma niyeti yerine mağaza memnuniyeti ve sadakati üzerinde daha fazla bir etki oluşturması bekleniyorsa hem sert hem de yumuşak faydalar bir arada sunularak tüketicilerin uzun vadede mağazaya olan bağlılığını sürdürülebilir kılmak mümkün olabilir.

Gerek uluslararası (örn. Homburg ve Giering, 2001; Bridson vd., 2008; Hussain, 2016), gerekse ulusal yazında (örn. Eren ve Erge, 2012; Alkoç, 2017) memnuniyetin müşteri sadakati yaratmada önemli bir değişken olduğunu belirten çalışmalar yer almaktadır. Ancak bu çalışmada, mağaza memnuniyetinin Gratis için mağaza sadakati oluşturduğu fakat Sephora için oluşturmadığı bulgusu elde edilmiştir. Keh ve Lee (2006), sadakat programlarının müşteri 
sadakatini arttırmak için tasarlandığını belirtmiş, ancak belirli bir memnuniyet eşiği seviyesine ulaşıldığında bu programların etkisinin belirgin hale geldiğini savunmuştur. Dolayısıyla Sephora'nın mağaza sadakati oluşturmak için mağaza memnuniyetini arttıracak çalışmalara ağırlık vermesi önerilebilir. Öte yandan, mağaza memnuniyetinin satın alma niyetiyle sonuçlanmayabileceği bu araştırmadaki her iki kozmetik perakendecisi için de geçerlidir. Literatürdeki çalışmalar bu bulguyu destekler nitelikte olup, mağaza memnuniyetinin satın alma niyetinde önemli bir etkisi olmadığı (Macintosh ve Lockshin; 1997) veya tek etken olamayacağı (Bennett ve Rundle-Thiele, 2004; Egan, 2000; Mcllroy ve Barnett, 2000) görüşü hâkimdir.

Son olarak, mağaza sadakatinin davranışsal boyutunun bir uzantısı olarak satın alma niyetini oluşturacağı önceki çalışmalarda bulgulanmıştır (örn. Caruana, 2002; Ranjbarian vd., 2012; Özcan ve Argan, 2014; Uzunkaya, 2016). Ancak bu araştırmada ortaya çıktığı üzere mağaza sadakati Gratis için satın alma niyeti oluştururken, Sephora için bir etki yaratmamıştır. Buradan hareketle, sadık tüketicilerin bile diğer perakendecilerde daha iyi bir değer elde etmeleri durumunda tercih değişikliği yapabileceği unutulmamalıdır.

$\mathrm{Bu}$ çalışmanın, kozmetik perakendecilerinin uyguladıkları sadakat programlarının tüketiciler üzerindeki etkisini inceleyen ilk araştırma olduğu düşünülmektedir. Bu anlamda pazarlama literatürüne ve yöneticilerine ciddi katkı sağlayacağı aşikar olsa da, çalışmanın kısıtları bazında bir değerlendirme yapılması gereği unutulmamalıdır. Örneklem seçim biçimiminin, büyüklüğünün ve yapısının bu araştırmadaki en önemli kısıt olduğunu belirtmek yanlış olmayacaktır. Zaman ve bütçe kısıtı nedeniyle kullanılan kolayda örneklem, sonuçların genellenmesi yönünde bir kısıt oluşturmaktadır. Her ne kadar veri analizinde kullanılan PLSSEM, küçük örneklemli araştırmalarda dahi, genellenebilir ve güvenilir sonuçlar verse de (Hair vd., 2012), ileriki çalışmalarda daha büyük bir örneklem ile hipotezlerin test edilmesi uygun olacaktır. Ayrıca cinsiyet, eğitim, gelir seviyesi vb. özellikler nezdinde dağılımın daha normal olduğu bir örneklem ile çalışmanın tekrarlanması önerilebilir. Bu çalışma bulgularının sadece kozmetik perakendecilerine yönelik çıktı sağladığı düşünülecek olursa, araştırmada kurgulanan modelin diğer sektörlerde test edildiği araştırmalar gerçekleştirilebilir.

\section{Kaynakça}

Ajzen, I. (1991). The theory of planned behaviour. Organizational Behavior and Human Decision Processes, 50(2), 179-211.

Akarsu, B. \& Akarsu, B. (2019). Bilimsel araştırma tasarımı - nicel, nitel ve karma araştırma yaklaşımları. İstanbul: Cinius.

Alkoç, K. Y. (2017). Üniversite imajı, üniversiteye duyulan memnuniyet ve öğrenci sadakati arasındaki ilişkileri anlamaya yönelik bir araştırma. Uluslararası Bilimsel Araştırmalar Dergisi, 2(2), 270-280. 
Anderson, J. C. \& Gerbing, D. W. (1988). Structural equation modeling in practice: A review and recommended two-step approach. Psychological Bulletin, 103(3), 411-423.

Assael, H. (1987). Consumer behavior and marketing action (4. Baskı), Boston: Kent.

Barlow, R. (1995). Five mistakes of frequency marketing. Direct Marketing, 57(11), 16-17.

Barlow, R. (1996). Agencies to consumers: Can we relate? Brandweek, 37(41), 40-42.

Bennett, R. \& Rundle-Thiele, S. (2004). Customer satisfaction should not be the only goal. Journal of Services Marketing, 18(7), 514-523.

Bloemer, J. \& De Ruyter, K. (1998). On the relationship between store image, store satisfaction and store loyalty. European Journal of Marketing, 33(5/6), 499-513.

Bojei, J., Julian, C. C., Wel, C. A. B. C. \& Ahmed, Z. U. (2013). The empirical link between relationship marketing tools and consumer retention in retail marketing. Journal of Consumer Behaviour, 12(3), 171-181.

Bolton, R., Lemon, K. N. \& Verhoef, P. C. (2002). The theoretical underpinnings of customer asset management: A framework and propositions for future research. Nashville, TN: Marketing Science Institute.

Bose, S. \& Rao, V. G. (2011). Perceived benefits of customer loyalty programs: Validating the scale in the Indian content. Management and Marketing, 6(4), 543-560.

Bozkuş, F. \& Yılmaz, Ö. B. (2018, Temmuz). Kozmetikte büyüme zamanı. Ekonomist. Erişim adresi: https://www.ekonomist.com.tr/kapak-konusu/kozmetikte-buyume-zamani.html

Bridson, K., Evans, J. \& Hickman, M. (2008). Assessing the relationship between loyalty program attributes, store satisfaction and store loyalty. Journal of Retailing and Consumer Services, 15(5), 364-374.

Capizzi, M. T. \& Furguson, R. (2005). Loyalty trends for the twenty-first century. Journal of Consumer Marketing, 22(2), 72-80.

Caruana, A. (2002). Service loyalty: The effects of service quality and the mediating role of customer satisfaction. European Journal of Marketing, 36(7/8), 811-828.

Cronin, J. J. \& Taylor, S. A. (1992). Measuring service quality: A reexamination and extension. Journal of Marketing, 56(3), 55-68.

Çakmak, A. Ç. \& Üster, Z. (2013). Mağaza kartlarının müşteri sadakatine etkisi: Kastamonu şehir merkezinde bir araştırma. KSÜ Sosyal Bilimler Dergisi, 10(2), 1-24.

Demoulin, N. T. M. \& Zidda, P. (2008). On the impact of loyalty cards on store loyalty: Does the customers' satisfaction with the reward scheme matter? Journal of Retailing and Consumer Services, 15(5), 386-398.

Day, G.S. (1969). A two-dimensional concept of brand loyalty. Journal of Advertising Research, 9(3), 29-35. 
Dorotic, M., T. Bijmolt, H. A. \& Verhoef, P. C. (2012). Loyalty programmes: Current konowledge and research directions. International Journal of Management Reviews, 14, 217-237.

Egan, J. (2000). Drivers to relational strategies in retailing. International Journal of Retail \& Distribution Management, 28(8), 379-386.

Eren, S. \& Erge, A. (2012). Marka güveni, marka memnuniyeti ve müşteri değerinin tüketicilerin marka sadakati üzerine etkisi, Journal of Yaşar University, 26(7), 4455-4482.

Fishbein, M. \& Ajzen, I. (1975). Belief, attitude, intention, and behavior: An introduction to theory and research. Reading, MA: Addison-Wesley.

Fornell, C. \& Larcker, D. F. (1981). Evaluating structural equation models with unobservable variables and measurement error. Journal of Marketing Research, 18(1), 39-50.

Furinto, A., Pawitra, T. \& Balqiah, T. E. (2009). Designing competitive loyalty programs: How types of program affect customer equity. Journal of Targeting, Measurement \& Analysis for Marketing, 17(4), 307-319.

Gratis. (t.y.). Gratis card. Erişim adresi: https://www.gratis.com/gratisCard

Gupta, S., Lehmann, D. R. \& Stuart, J. A. (2004). Valuing customers. Journal of Marketing Research, 41(1), 7-18.

Hair, J. H., Black, W. C., Babin, B. J. \& Anderson, R. E. (2010). Multivariate data analysis (7. Baskı). USA: Pearson.

Hair, J. F., Hult, G. T. M., Ringle, C. M. \& Sarstedt, M. (2017). A primer on Partial Least Squares Structural Equation Modeling (PLS-SEM) (2. Bask1). Thousands Oak, CA: Sage.

Hair, J., Sarstedt, M., Ringle, C. \& Mena, J. (2012). An assessment of the use of Partial Least Squares Structural Equation Modeling in marketing research. Journal of the Academy of Marketing Science, 40(3), 414-433.

Hanzaee, K. H. \& Rezaeyeh, S. P. (2013). Investigation of the effects of hedonic value and utilitarian value on customer satisfaction and behavioural intentions. African Journal of Business Management, 7(11), 818-825.

Harris, E. (2000). Recognize, reward, reap the benefits. Sales and Marketing Management, 152(9), 109-119.

Harris, L. C. \& Goode, M. M. H. (2004). The four levels of loyalty and the pivotal role of trust: A study of online service dynamics. Journal of Retailing, 80(2), 139-158.

Henseler, J., Hubona, G. \& Ray, P. A. (2016). Using PLS Path Modeling in new technology research: Updated guidelines. Industrial Management \& Data Systems, 116(1), 2-20.

Henseler, J., Ringle, C. M. \& Sinkovics, R. R. (2009). The use of Partial Least Squares Path Modeling in international marketing. R. R. Sinkovics \& P. N. Ghauri (Ed.), Advances in International Marketing (s. 277-320) içinde. Bingley: Emerald. 
Homburg, C. \& Giering, A. (2001). Personal characteristics as moderators of the relationship between customer satisfaction and loyalty-An Empirical Analysis. Psychology and Marketing, 18(1), 43-66.

Hunt, S., Arnett, D. \& Madhavaram, S. (2006). The explanatory foundations of relationship marketing theory. Journal of Business \& Industrial Marketing, 21(2), 72-87.

Hussain, R. (2016). The mediating role of customer satisfaction: Evidence from the airline industry. Asia Pacific Journal of Marketing and Logistics, 28(2), 234-255.

Jacoby, J. \& Chestnut, R.W. (1978). Brand loyalty measurement and management. New York: Wiley.

Johnson, M. D. \& Fornell, C. (1991). A framework for comparing customer satisfaction across individuals and product categories. Journal of Economic Psychology, 12(2), 267-286.

Kang, J., Alejandro, T. B. \& Groza, M. D. (2015). Customer-company identification and the effectiveness of loyalty programs. Journal of Business Research, 68(2), 464-471.

Keh, H. T. \& Lee, Y. H. (2006). Do reward programs build loyalty for services? The moderating effect of satisfaction on type and timing of rewards. Journal of Retailing, 82, 127-136.

Kendrick, A. (1998). Promotional products vs. price promotion in fostering customer loyalty: A report of two controlled field experiments. The Journal of Services Marketing, 12(4), 312-326.

Ketchup Loyalty Marketing. (t.y.). 2017-2018 Ketchup sadakat programları araştırması yayınlandı! Erişim adresi: http://www.ketchuployalty.com/blog/2017-2018-sadakatprogramlari-arastirmasi-yayinda/

Kırım, A. (2001). Strateji ve bire-bir pazarlama CRM. İstanbul: Sistem.

Kim, H. Y., Lee, J. Y., Choi, D., Wu, J. \& Johnson, K. K. P. (2013). Perceived benefits of retail loyalty programs: their effects on program loyalty and customer loyalty. Journal of Relationship Marketing, 12(2), 95-113.

Knox, S. D. \& Denison, T. J. (2000). Store loyalty: Its impact on retail revenue, an emprical study of purchasing behaviour in the UK. Journal of Retailing and Consumer Services, 7(1), 3345.

Kozmetik Dünyası Online Atağına Geçti. (2019). Ekonomist (7 Haziran). Erişim adresi: https://www.ekonomist.com.tr/perakende/kozmetik-dunyasi-online-atagina-gecti.html

Kyguoliene, A., Zikiene, K. \& Grigaliunaite, V. (2017). The influence of perceived benefits on the satisfaction with the loyalty program. Inzinerine Ekonomika-Engineering Economics, 28(1), 101-109.

Lacey, R. \& Sneath, J. Z. (2006). Customer loyalty programs: Are they fair to consumers? Journal of Consumer Marketing, 23(7), 458-464. 
Leenheer, J., van Heerde, H. J., Bijmolt, T. H. A. \& Smidts, A. (2007). Do loyalty programs really enhance behavioral loyalty? An empirical analysis accounting for self-selected members. International Journal of Research in Marketing, 24, 31-47.

Liu, Y. (2007). The long-term impact of loyalty programs. Journal of Marketing, 71, 19-35.

Macintosh G. \& Lockshin, L. S. (1997). Retail relationships and store loyalty: A multi-level perspective. International Journal of Research in Marketing, 14, 487-497.

Mcllroy, A. \& Barnett, S. (2000). Building customer relationships: Do discount cards work? Managing Service Quality, 10(6), 347-355.

Melancon, J. P., Noble, S. M. \& Noble, C. H. (2011). Managing rewards to enhance relational worth. Journal of the Academy of Marketing Science, 39, 341-362.

Mimouni-Chaabane, A. \& Volle, P. (2010). Perceived benefits of loyalty programs: Scale development and implications for relational strategies. Journal of Business Research, 63, 32-37.

Noordhoff, C., Pauwels P. \& Schröder, G. O. (2004). The effect of customer card programs a comparative study in Singapore and the Netherlands. International Journal of Service Industry Management, 15(4), 351-364.

Nunnally, J. (1978). Psychometric methods. New York: McGraw-Hill.

Odabaşı, Y. (2000). Satışta ve pazarlamada müşteri ilişkileri yönetimi. İstanbul: Sistem.

Oliver, R. L. (1980). A cognitive model of the antecedents and consequences of satisfaction decisions. Journal of Marketing Research, 17(4), 460-469.

Oliver, R. L. (1997). Satisfaction: A behavioral perspective on the customer. New York: McGrawHill.

Oliver, R., Rust, L. \& Varki, S. (1997). Customer delight: Foundations, findings and managerial insight. Journal of Retailing, 73(3), 311-336.

O'Malley, L. (1998). Can loyalty shemes really build loyalty? Marketing Intelligence \& Planning. 16(11), 47-55.

Omar, N. A., Ramly, S. M., Alam, S. S. \& Nazri, M. A. (2015). Assessing the effect of loyalty program benefits in satisfaction-loyalty relationship: Evidence from Malaysia. Jurnal Pengurusan, 43, 145-159.

Oyman, M. (2002). Müşteri sadakati sağlamada sadakat programlarının önemi. Kurgu Dergisi, 19, 169-185.

Öz, Ö. (2006). Birebir pazarlamada müşterilerin sadakat göstergelerinin incelenmesi: Örnek bir firmada araştırma (Yayımlanmamış Yüksek Lisans Tezi). Akdeniz Üniversitesi/Sosyal Bilimler Enstitüsü, Antalya. 
Özcan, M. \& Argan, M. (2014). Tüketiciyle online (çevrimiçi) bağ kurma ile sadakat ve yeniden satın alma niyeti arasındaki ilişki: Facebook örneği. Tüketici ve Tüketim Araştırmaları Dergisi, 6(1), 51-82.

Özer, S. U. (2015). İstanbul' da faaliyet gösteren beş yıldızlı otel işletmelerinin müşteri sadakat programlarının içerik analizi. Ekonomi ve Yönetim Araştırmaları Dergisi, 4(1), 134-157.

Öztürk, S. A. (2003). Hizmet pazarlaması. Bursa: Ekin.

Price, L., Arnould, E. J. \& Tierney, P. (1995). Going to extremes: Managing service encounters and assessing provider performance. Journal of Marketing, 59(4), 83-97.

Radder, L., Eyk, van M. \& Swiegelarr, C. (2015). Levels of customer loyalty and perceptions of loyalty programme benefits: A South Africa retail example. The Retail and Marketing Review, 11(1), 92-105.

Ranjbarian, B., Sanayei, A., Kaboli, M. \& Hadadian, A. (2012). An analysis of brand image, perceived quality, customer satisfaction and re-purchase intention in Iranian department stores. International Journal of Business and Management, 7(6), 40-48.

Ruzeviciute, R. \& Kamleitner, B. (2017). Attracting new customers to loyalty programs: The effectiveness of monetary versus non-monetary loyalty programs. Journal of Consumer Behaviour, 16(6). 113-124.

Selvi, M., Özkoç, H. \& Emeç, H. (2016). Mağaza imajı, mağaza memnuniyeti ve mağaza sadakati arasındaki ilişkinin tüketiciler açısından değerlendirilmesi. Dokuz Eylül Üniversitesi İktisadi İdari Bilimler Fakültesi Dergisi, 22(1), 105-121.

Sephora. (t.y.). Sephora kart. Erişim adresi: https://www.sephora.com.tr/sephora-kartim

Sharp, B. \& Sharp, A. (1997). Loyalty programs and their impact on repeat-purchase loyalty patterns. International Journal of Research in Marketing, 14(5), 473-486.

Sheth, J. N. (1996). Organizational buying behavior: Past performance and future expectations. Journal of Business \& Industrial Marketing, 11(3/4), 7-24.

Solomon, M. R. (1996). Consumer behavior: Buying, having and being. Mexico: Prentice-Hall.

Sreejesh, S., Sarkar, A. \& Pradhan, S. (2016). Examining the roles played by a store satisfactionlove framework in shaping the influence of store loyalty programs. Management Research Review, 39(8), 879-898.

Taylor, G. A. \& Neslin, S. A. (2005). The current and future sales impact of a retail frequency reward program. Journal of Retailing, 81(4), 293-305.

Tek, Ö. B. \& Özgül, E. (2005). Modern pazarlama ilkeleri. İzmir: Birleşik.

Tietje, B. (2002). When do rewards have enhancement effects? An availability valence approach. Journal of Consumer Psychology, 12(4), 363-373. 
Uncles, M. D., Dowling, G. \& Hammond, K. (2003). Customer loyalty and customer loyalty programs. Journal of Consumer Marketing, 20(4), 294-316.

Usta, A. (2012). Sorunsaldan sonuçlara bilimsel araştırma süreci: Bir araştırma raporu modeli örneği. ODÜ Sosyal Bilimler Enstitüsü Sosyal Bilimler Aratırmaları Dergisi, 3(5), 135-161.

Uzunkaya, T. (2016). Marka sadakatinin tekrar satın alma niyetine etkisi ve GSM sektöründe bir araştırma. Beykent Üniversitesi Sosyal Bilimler Dergisi, 9(2), 58-67.

Yeniçeri, T. \& Erten, E. (2011). Mağaza sadakat programlarının algılanması, güven, ilişkiyi sürdürme isteği ve mağaza sadakati arasındaki ilişkilerin yapısal eşitlik modeli ile incelenmesi. Doğuş Üniversitesi Dergisi, 9(2), 232-247.

Wulf, K. \& Odekerken-Schröder, G. (2003). Assessing the impact of a retailer's relationship efforts on consumers' attitudes and behavior. Journal of Retailing and Consumer Services, 10(2), 95-108. 